\title{
RELATO DE CASO: ABORDAGEM DE PIELONEFRITE AGUDA EM PACIENTE IDOSO NO PRONTO SOCORRO
}

\author{
CASE REPORT: MANAGEMENT OF ACUTE PYELONEPHRITIS IN ELDERLY \\ PATIENT AT THE EMERGENCY ROOM
}

\author{
Laura Zabisky Floresta $^{1 *}$, Isabela Zabisky Floresta ${ }^{2}$, Luís Eduardo Cury \\ Guerra $^{3}$.
}

'UNINGÁ - Centro Universitário Ingá, Maringá, PR, Brasil.

2UNICESUMAR - Centro Universitário Cesumar, Maringá, PR, Brasil.

${ }^{3}$ Faculdade de Medicina de Rio Verde, Aparecida de Goiânia, GO, Brasil.

*laurazabiskyfloresta@gmail.com

\section{RESUMO}

A pielonefrite é uma infecção do trato urinário superior que envolve os rins, na qual a maioria dos episódios são considerados não complicados em adultos saudáveis. Diferentes fatores de risco estão associados como, diabetes, obstrução do trato urinário, presença de cateter uretral por período prolongado, nefrostomia, anormalidades funcionais ou anatômicas do trato urinário, transplante renal, terapia imunossupressora e gravidez. As manifestações clínicas mais frequentes são febre, calafrios, dor na região de flanco e enjoo. Em pacientes idosos as manifestações clínicas podem ser atípicas. O objetivo é relatar 0 atendimento de paciente idosa com suspeita de pielonefrite aguda posterior a realização de litotripsia renal. Paciente do sexo feminino, 76 anos, viúva, aposentada, procurou atendimento com queixa de dor lombar, calafrios, febre intermitente, disúria, polaciúria e náuseas há 4 dias. Apresentava dor lombar de forte intensidade e dor leve em abdome inferior, sem fatores de melhora ou piora, de caráter contínuo com irradiação para fossa ilíaca esquerda. História mórbida pregressa de infecção do trato urinário de repetição, nefrolitíase à esquerda, hidronefrose moderada à esquerda e leve à direita. Realizou litotripsia renal a laser aproximadamente há um mês. Ao exame físico se encontrava em estado geral regular, lúcida e orientada. Temperatura axilar: $38^{\circ}$ C. PA:100 x $70 \mathrm{mmHg}$. FC: 85 bpm. SAT O2 96\% ar ambiente. FR: $18 \mathrm{irpm}$. Aparelho respiratório sem anormalidades. ABD: sem dor à palpação superficial ou profunda. Apresentava sinal de Giordano positivo bilateral. A hipótese diagnóstica principal foi pielonefrite aguda. Para confirmação foram solicitados exames laboratoriais. Hemograma: leucócitos: 11.320/ mm³. Hb 10,6 g/dL. Plaquetas: $179 \mathrm{mil} / \mathrm{mm}^{3}$. Urina 1: Leucocitúria. Hematúria. Proteinúria. Nitrito positivo. Urocultura: indicava presença de Klebsiella spp sensível a Imipenem e Meropenem. O diagnóstico diferencial mais provável considerado foi cistite complicada, entretanto, a presença de sinal de Giordano positivo bilateral, febre e rebaixamento no estado geral da paciente são indicativos de pielonefrite aguda. Confirmado o diagnóstico, o tratamento inicial foi efetuado por meio do uso de Cloridrato de Ondansetrona, Butilbrometo de Escopolamina e Dipirona Sódica em caso de dor abdominal ou febre. Ao receber os resultados da urocultura foi iniciado o tratamento com Imipenem. A paciente evoluiu sem complicações, se manteve estável e recebeu alta após 7 dias com 
recomendação de acompanhamento por serviço de nefrologia. Conclui-se, desse modo, que o diagnóstico foi correto e o tratamento foi efetivo sendo baseado na urocultura indicativa de sensibilidade da Klebsiella spp. ao Imipenem.

Palavras-chave: Hidronefrose. Infecção urinária. Litotripsia renal. Nefrolitíase. Pielonefrite. 